Article

\title{
A Framework for European Thought on Psychology, Education and Health Based on Foucault's The Order of Things
}

\author{
Carol Nash
}

History of Medicine Program, Department of Psychiatry, Temerty Faculty of Medicine, University of Toronto, Toronto, ON M5S 1A1, Canada

\begin{abstract}
In European thought, the relationship among the fields of psychology, education, and health is both complex and obscured. Foucault's acclaimed work, The Order of Things, offers a framework to evaluate their interconnection by identifying three distinct periods of European thought since the $16^{\text {th }}$ century with respect to the ordering of phenomena-Renaissance, Classical and Modern. Theoretically dense and often difficult to decipher, the book's categorization of language, value and being has been understandably underused, yet it provides deep insights into what have come to be known as psychology, education and health and remains invaluable in understanding the origin, limits and consequences of these fields. How Foucault's analysis can be interpreted concerning the development of these areas as to each of the three periods of European thought is investigated. An approach based on narrative research appraises the analysis offered in the book. The results, presented for the first time in table form, compare these three periods, demonstrating a continuing practical value to Foucault's insights. With the aid of the framework revealed by these tables, the boundaries and relationship of psychology, education and health become clear and their limitations - plus potential solutions to them - can be identified to mitigate anticipated negative consequences.
\end{abstract}

Keywords: European thought; psychology; education; health; Foucault; The Order of Things; framework; narrative research

\section{Introduction}

The relationship among psychology, education and health within European thought is an important foundational consideration in a European journal such as this one, devoted to investigations in health, psychology and education. It is one that remains complex and unclear $[1,2,3]$. With no evidently necessary connection, these fields have recently been joined in various ways in a number of investigations in European thought, including but not limited to, (1) the use of mobile-based psychological interventions to provide education regarding mental health [4], (2) patient education with respect to healthcare through the elimination of psychological jargon [5], (3) the adoption of a health approach to psychological interventions focused on psycho-education [6], (4) the use of psychological measures to explore health literacy and health education [7], and (5) a psychological analysis of personality traits with reference to education and health [8]. Within this particular journal, a recent publication has focused on the mental health of international university students from the perspective of psychology and education researchers [9]. For these and other investigations undertaken by researchers with respect to European thought, it would be important to know the confines and presuppositions for each of psychology, education and health and their relationship to each other.

The Order of Things: The Archeology of Human Sciences was first published by French historian of ideas Michel Foucault in 1966 under the title Les mots et les choses: Une archéologie des sciences humaines [10]. It was translated to English in 1970 [11] and ranks number 66 in Le Monde's 100 Books of $20^{\text {th }}$ Century [12], continuing to hold interest for scholars in psychology, in education and in health with respect to their research. Recent articles based 
on this book have demonstrated various foci in these areas: understanding emotions in policy studies [13], critical and theoretical reflection on the current mathematics educational objectives for Indigenous students in Australia [14], and the role of social media and the internet in providing credible, reliable and objective sources of sexual health information for young people [15].

Noting the complexity of The Order of Things since its translation, over the years researchers from various perspectives have attempted to summarize the work and make it intelligible $[16,17,18,19,20]$. Yet, although interest in the book has remained for more than fifty years, there has been no attempt until now to make Foucault's work obvious to scholars with respect to the interrelation of psychology, education and health in order to point to the boundaries and limitations inherent to these fields.

Narrative research is one of the five methods of qualitative inquiry (phenomenological psychology, grounded theory, discourse analysis and intuitive inquiry representing the other four [21]). It has been defined as the varying perspectives of a story that can be constructed to make experience comprehensible [22] (p. 37), the treatment of data as stories [23] where narrative data are the result of a communication exchange [24] and an understanding of how human actions are related to the social context in which they occur including where and how [25]. In choosing narrative research to investigate The Order of Things, it is recognized both that Foucault tells a story about the differences among the three periods of scientific thinking he identifies and, at the same time, that this story does not follow an obvious plot and has a literary structure that has been described as "baroque" [26] (p. 449). Primarily, this meandering plot is what makes the analysis offered in the book so difficult to decipher. Nevertheless, the data are there to be extracted and interpreted if time is taken and concentration maintained to perform the investigation.

Unlike other well-known researchers assessing the limits of scientific pursuits from the perspective of what universally counts as rational $[27,28,29]$, Foucault argues that the development of modes of rationality in European thought are specific and transient-differing from another alternative view of science (that it is primarily an irrational enterprise [30]). As such what counts as a reasonable from Foucault's perspective is not timeless [31], although it is still rational. It is in this way that Foucault develops his idea that scientific problems in European thought have changed historically and the identities of individual periods can be known, compared and analyzed. Furthermore, in arguing different periods in European thought to be incommensurable in relation to ordering, clear sense can be made of the idea that certain propositions in science are "not even wrong" [32]. And although there were other social scientists at the time of the publication of The Order of Things who also elucidated a micro-scale analysis of the history of scientific research from an interpretive rather than normative perspective [33], Foucault's work was both the most detailed and has remained most lasting in this endeavor. For these reasons, unlike other perspectives, it still retains usefulness as a conceptual system for European thought.

\section{Materials and Methods}

The narrative research method undertaken to examine The Order of Things was a detailed reading of the book over a two year period. This involved not only a twice-reading of the 422 page paperback book, cover to cover, but also comparing and contrasting different sections and themes in relation to particular issues on the second reading. Foucault, although discussing three scientific periods of ordering phenomena in his book-Renaissance, Classical and Modern - focuses primarily on comparing the Classical and Modern periods. His interest in the Renaissance period is transitory and does not follow the same detailed structure of interpretation he provides for the Classical and Modern periods (with the Classical period presenting the greater attention of the two). As such, an investigator of what Foucault has to say about the Renaissance period (beginning for the purpose of his analysis in the $16^{\text {th }}$ century [11] (p. 421)) must dig deeply into the little he offers about the Renaissance period to compare it in a way that is similar to the relationships he draws between the Classical and Modern periods. Why this excavation of Foucault's 
analysis of the Renaissance period is of equal relevance this in regard is that, by comping the three periods, Foucault's argument-regarding the periodic, incommensurable changes in scientific reasoning - becomes evident.

The lack of an index to the book is a serious hindrance to proceeding in a narrative analysis of The Order of Things, given there is no helpful way for a researcher to find themes, ideas and references in the work. This is especially so since it is only relatively recently that an electronic version of the volume has been available to scrutinize [34]. Therefore, to undertake a narrative analysis of the book, the chapter headings offered by Foucault must be used as the starting point for interpreting the structure presented.

Although the three historical periods are discussed chronologically, it is the three middle chapters, amounting to almost half of the work, that set the parameters for the discussion. These are: Chapter 4-Speaking, Chapter 5-Classifying, and Chapter 6-Exchanging. Together, they represent the three fundamental ways that Foucault sees the Classical period as ordering things. Understanding these divisions as pivotal to Foucault's thinking, a narrative research approach can move forward to Part II where Foucault's ordering of the Modern period is revealed in Chapter 8 through its title- "Labour, Life and Language". It is in moving forward to Chapter 8 that it becomes evident the evolution of thought from the Classical period to the Modern came with a shift in interest in the same domain from 'Speaking to Language', from 'Classifying to Life', and from 'Exchanging to Labour'. What remained to be realized was the common categories under which these shifts took place. Yet, before this could be interpreted, the similarly relevant categories pertaining to the Renaissance needed to be recognized.

Unlike his account of the Classical or Modern periods, Foucault has not provided chapter headings that point researchers to what he identified as how things were ordered during the Renaissance. Nevertheless, by reading through both Chapter 2 - "The Prose of the World", and Chapter 3-"Representing", the ideas of how the Renaissance was ordered in comparison to both the Classical and Modern periods can be disentangled. What Foucault argues is that during the Renaissance order was fundamentally dependent on a broad notion of resemblances-if one thing resembled another, in whatever way, knowledge of the one thing represented what was known about the other. Ultimately, the end point of this resemblance was coming to know the mind of God. In this way, human utterances were the ideas of God, what was of value among humans was a relation to the perfection of God, and what represented being during the Renaissance was how closely living was structured to adhere to signs of God's work. In this way, what is normally considered the superstitious nature of the Renaissance in looking for signs - for example, in the stars or animal entrails [35] - was instead, according to Foucault's view, a completely structured way of trying to account for things. Although very different in understanding, Foucault is not alone in considering the Renaissance method of ordering the beginning of scientific thought because of its focus on ordering [36].

According to Foucault's analysis, what changed between the time of the Renaissance and that of the $17^{\text {th }}$ and $18^{\text {th }}$ centuries of the Classical period was that God, though still the end to all ordering, was no longer the focus. Rather, what Foucault labels "Mathesis and "Taxinomia'" [11] (p. 79) now became not only the methods of reaching God, they were, in and of themselves, what was to be studied. This was the beginning of the importance of the infinitesimal in ordering sensations, wealth, and ideas into tables noting minute, precise and microscopic changes. In making these fine observations, the observer now also came into focus with wondering what is the " $\mathrm{I}$ " that can make these distinctionscharacterized in Descartes's well known, 1637, phrase "cognito, ergo sum" (I think, therefore I am) [37] (p. 53). With respect to language, words were no longer signs of God's thoughts. Instead, built up through individual sounds represented by letters, words were the evolution in language of the initial cries of prehistoric ancestors.

In Foucault's estimation, what changed to create the Modern period of ordering was attention shifting from who is the observer to what the observer is not. Science now became disassociated with searching for a connection to God. Instead, scientific reasoning 
became the search for what was not known. In effect, the known and unknown became a couplet, logically impossible to separate. The minute divisions of European thought during the Classical period no longer were the foundation for ordering. Within language, research shifted from the origin of letters and words to the what was seen as an organic structure of verbs regarding their conjugations. The relationships among languages shifted once how language worked became key, rather than similarities in letters and words - now seen as irrelevant. Regarding exchange, pinpointing the organic created the idea of economics over that of accumulated wealth. As such, value shifted from ownership to what labor was able to produce. Similarly, ordering was no longer related to a connection to God - as in the Renaissance - or to very particular features that could be precisely enumerated-as in the Classical period. This concentration also meant that being alive depended on the systems of differing internal organs that could and must be studied and understood independently.

In using narrative research to construct what it is that draws together each of these three aspects of these three periods of ordering in European thought, the only distinctions that can be made are ones that can be found in The Order of Things. As Foucault himself does not bring together the connection among these ways ordering, and it is not to be found in chapter or section headings, the text itself must be examined through a close reading to find words that Foucault uses in describing all three periods. As such, although it might seem reasonable to refer to the three fundamental aspects of ordering Foucault recognizes in each of the three periods as "communication, value and being", in the English translation, Foucault never uses the word "communication". He does, however, refer to "language" in each of the three periods. Why this is not an ideal choice, though, is "language" is also used by Foucault as a principle of ordering particular to the Modern period. Therefore, if there were another word that could take the place of "language" in the fundamental ordering, this would be preferred. However, no more appropriate word was able to be located in the text. As such, "language, value and being" were determined to be the best fit in creating a table representing Foucault's method of ordering phenomena.

\section{Results}

\subsection{Lanuage, Value, Being}

The following construction in Table 1 represents Foucault's three periods of European Thought with respect to the three aspects he considers fundamental to ordering.

Table 1. Three fundamental aspects of order-language, value and being-ascertained from Foucault's The Order of Things as they relate to the three most recent periods of European thought with respect to the ordering of things.

\begin{tabular}{|c|c|c|c|}
\hline \multirow[b]{2}{*}{ Period of European Thought } & \multicolumn{3}{|c|}{$\begin{array}{c}\text { Fundamental Aspects } \\
\text { of Order }\end{array}$} \\
\hline & language & value & being \\
\hline Renaissance & $\begin{array}{c}\text { Recognition } \\
\text { of } \\
\text { signatures }\end{array}$ & $\begin{array}{c}\text { Resemblance } \\
\text { to } \\
\text { God's perfection }\end{array}$ & $\begin{array}{c}\text { Structure } \\
\text { dependent on } \\
\text { signs }\end{array}$ \\
\hline Classical & $\begin{array}{l}\text { Connection } \\
\text { to } \\
\text { original cries }\end{array}$ & $\begin{array}{c}\text { Accumulation } \\
\text { of } \\
\text { wealth } \\
\end{array}$ & $\begin{array}{l}\text { Structure } \\
\text { dependent } \\
\text { on "I" }\end{array}$ \\
\hline Modern & $\begin{array}{c}\text { Conjugation } \\
\text { of } \\
\text { verbs }\end{array}$ & $\begin{array}{c}\text { Production } \\
\text { by } \\
\text { labor } \\
\end{array}$ & $\begin{array}{c}\text { Structure } \\
\text { dependent on } \\
\text { organic function }\end{array}$ \\
\hline
\end{tabular}

Each of the rows in Table 1 represents a fully intact conceptual system incompatible with the other systems of ordering. Rather than the Renaissance and Classical periods being ill-formed versions of scientific ordering that had to evolve into the Modern period 
to be understandable, these three systems are each complete in themselves and have little relationship among them with respect to the presuppositions they demand. As such, all of these systems of thought have well-defined boundaries and are based on evident rules.

The Renaissance, rather than a period of confused and apprehensive thought as generally assumed [38], started with the notion that God's thoughts are everywhere, that they are subtle, but can be disentangled by comparing similar signatures left of God's perfection in signs. As such, there was an exact and learnable system for ordering the world.

With respect to the Classical period, there was a seismic shift in thinking that changed all that was then presupposed from that of the Renaissance. This shift differs both theoretically and functionally from Kuhn's notion of a revolution in paradigm [39] as Foucault sees ordering as based on structures of human thought rather than sociological influences [40]. During the Classical period, although God was the beginning and end to inquiry, luck in outcomes, and the structured and infinitesimal observation scientists could undertake, left no place for God during the process of ordering [41]. Furthermore, the idea of the observer as affecting the outcome of inquiry was brought to consciousness with the identification of "I" [42].

The Modern period brought with it again an entire change of perspective in European thought. God was no longer a relevant consideration in ordering from the point of view of science. Rather, the idea of organs having particular and independent functions from each other that could be studied in isolation was born-organic was then differentiated from the inorganic [43] and found to be of use in the ordering of European thought in the study of phenomena through disciplinary subjects [44]. The role of science thus became identified with what is known in relation to the pursuit of the unknown [45].

\subsection{Psychology, Education and Health}

The results of the construction of Table 1 in highlighting the three fundamental aspects of order as revealed by Foucault in The Order of Things may now be used to examine how this ordering relates to psychology, education and health as distinct disciplines in European thought. This can be determined by adhering to Foucault's contention that "three pairs of function and norm, conflict and rule, signification and system completely cover the entire domain of what can be known about man" [11] (p. 390) with the results of this analysis presented in Table 2 .

Table 2. Three aspects of order (psychology, education and health) based on Foucault's The Order of Things-with respect to language, value and being -in relation to the three most recent periods of European thought in regards to ordering (recognizing that the term "psychology" originated in the Modern period) comparable in all three periods.

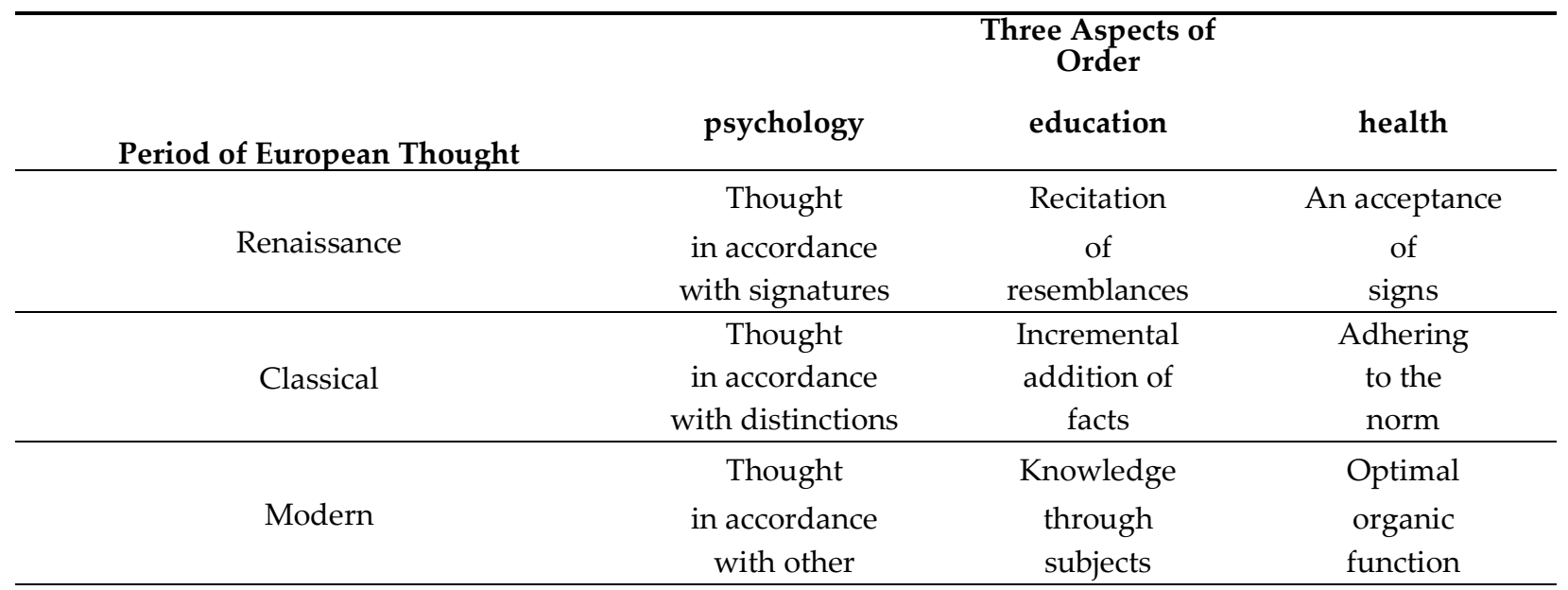

Although the divisions of study of psychology, education and health are comprehensible to researchers in the Modern period, psychology was unknown before the Modern period. Yet, sense can be made of what scholars in the Renaissance and Classical periods would consider in relation to what is now called psychology if the three couplets 
Foucault presents as covering the entire domain of knowledge are considered. Still, when assessing these couplets, Foucault provides additional information in only a few paragraphs of his book that might be missed without a close reading.

Throughout almost the entirety of The Order of Thing, Foucault confirms that since the $16^{\text {th }}$ century there have been three distinct periods of ordering in European thought. These have been highlighted. However, on page 392, Foucault reveals that the Modern period is actually not uniform - there have been three sub-eras into which the Modern period can be divided. The first, arising in the $19^{\text {th }}$ century, was the biological model. During this era, psychology was concerned with the dichotomy between function and norm. After that, as the $19^{\text {th }}$ century transitioned to the $20^{\text {th }}$, the economic model could be applied to psychology as the locus of conflicts with respect to rule following took hold of the imagination. Following this era was the beginning of psychology related to the significance of different systems of thinking with the linguistic model. These changes over the Modern period are presented in Table 3. Foucault reveals these changes in thinking regarding psychology to be the influence of three thinkers who originated these changes in the domains of ordering during the Modern period-Comte, Marx and Freud.

Table 3. The psychological eras that the Modern period of European thought can be divided into according to Foucault's The Order of Things.

\begin{tabular}{cc}
\hline Modern period era & Model of psychological reasoning \\
\hline $19^{\text {th }}$ century & biological \\
Cusp, $19^{\text {th }} / 20^{\text {th }}$ century & economic \\
$20^{\text {th }}$ century & linguistic \\
\hline
\end{tabular}

It is important to mention this change to ordering during the Modern period. The reason is Foucault clearly states [11] (page 390) that "psychology is fundamentally a study of man in terms of functions and norms (functions and norms which can, in a secondary fashion, be interpreted on the basis of conflicts and significations, rules and systems)". Yet, this pronouncement occurs before he acknowledges that the Modern period has itself modified how it orders psychological reasoning into three distinct eras. Based on what he relates two pages later, it becomes clear that, in interpreting Table 2, psychology, in this regard, became an area that provides assessment of the signification of what is thought based on various systems of interpretation, "Freud... brought the knowledge of man closer to its philological and linguistic model" [11] (p. 393). In this same regard, education becomes the effort to diminish intellectual and social conflict through the teaching of various rules. Health then concerns the body's functions in relation to what is revealed to be the norm through empirical testing.

\subsection{Ordering from Question-Asking}

From Foucault's tri-system of ordering, how information is recognized for the purpose of ordering can be interpreted. As such, questions need to be posed to identify what things are legitimate as knowledge to be ordered. For Foucault, the legitimacy of questions changed dramatically over the three periods of European as seen in Table 4 .

During the Renaissance, what counted as objective knowledge was a response an investigator would give when presented with individual signs. Each sign was considered to point to the thoughts originating with God and the role of the researcher was to identify the correct response when presented with a sign. Although Foucault does not provide an example, one that might be supposed is the continued concern of Renaissance scholars to adhere to the idea that the orbits of the planets must be circular and earth the center of the solar system because God was perfection. This necessitated finding a way to demonstrate this perfection [46]. It wasn't that Copernicus, in 1543, was the first astronomer to recognize that the orbit of the planets wasn't best approached through 
circular motion [47], it was that scientific ordering at that time related to finding resemblances with respect to the perfection of God - a completely different approach to ordering than was no longer accepted after the Classical period took hold of the European imagination.

Once the Classical period ensued, and the focus of knowledge became the gathering of facts infinitesimally divided, question-asking was no longer related to interpreting God's thoughts. Instead, the focus was on whether a thing was true or false [48] (p. 437). This was best determined by these binary responses in observing and documenting the natural world. In his section on Classifying, Foucault clarifies that this new domain of the empirical concentrated on what was describable and orderable with the use of tables.

The Modern period, concerned with the functional interpretation of systems and rules, requires a form of question-asking that depends on the extent of language usage. As such, to order things, researchers are required to answer a series of questions starting from the most objective and obvious to those that require subjective interpretation. These questions, then, follow an objective to subjective order of posing: when, where, who what, how and why. It is this a form of question-asking that has been described as moving from knowledge structures to inferring to decision making to metacognition [49].

Table 4. The forms of question-asking to provide knowledge that can be analyzed from Foucault's The Order of Things - with respect to language, value and being - in association with the three most recent periods of European thought.

\begin{tabular}{cc}
\hline $\begin{array}{c}\text { Period of European } \\
\text { thought }\end{array}$ & Form of question-asking to provide knowledge \\
\hline Renaissance & Responses indicated and dictated by signs \\
Classical & Those eliciting "true" and "false" answers \\
Modern & Asking when, where, who, what, how, why \\
\hline
\end{tabular}

\subsection{Question Responses in the Moderrn Period of Ordering}

In being a response to the type of questions posed, answers provide that which is to be ordered. The type of question-asking relevant to the Modern period can then be applied to Foucault's account of the Modern period in The Order of Things. In asking when the Modern period of European thought originated, the answer is from the $19^{\text {th }}$ century. It has continued from then until today. Where it began was in France, in Germany and in Austria. Who were the forefathers of the Modern period Foucault recognizes as Comte $[50,51]$ (the originator of positivism), Marx [52,53] (the founder of the labor theory of economics), and Freud [54,55] (for his understanding of the body function as depending on the subtlies of the subconscious). What was introduced were the research disciplines of philogy, economics and biology. How this was done was by the development of a hierarchy of subject areas [56]. Why this ordering was put into place is, according to Foucault, the idea of "man" as and entity to study - regarding what man is and what man is not-first came into being at this time. Before the Modern period, Foucault argues, the notion of man as something to be studied did not exist.

Table 5. The form of scientific question-asking responses analyzable from Foucault's The Order of Things regarding the modern period of European thought.

\begin{tabular}{cc}
\hline Type of question asked & Response in Modern period \\
\hline when & $19^{\text {th }}$ century $\rightarrow$ now \\
where & Originating in France, Germany and Austria \\
who & August Comte, Karl Marx, Sigmund Freud \\
what & Philology, Economics, Biology \\
how & Developing thought through a hierarchy of subjects \\
why & Creation of "man" as the focus of order \\
\hline
\end{tabular}




\section{Discussion}

In discussing the significance of the analysis that has been provided of The Order of Things with respect to European thought regarding psychology, education and health, reference will first be made to Table 2 and a detailed explanation of the meaning of each of the nine cells. Following that, Table 4 will be considered in relation to this understanding that has been provided of Table 2 .

\subsection{Table 2}

Table 2 represents a grid comparing the three periods of ordering since the $16^{\text {th }}$ century, identified by Foucault, in relation to the three aspects of ordering that are the focus of the European Journal of Investigation in Health, Psychology and Education: psychology, education and health. This table is based on an interpretation of Table 1, which compared these same three periods with what Foucault reasoned were the three fundamental aspects of ordering. The individual cells of this grid will be elucidated upon from top to bottom and left to right, going in historical order and with respect to the dependent relationship of these aspects.

\subsubsection{Renaissance}

Although psychology did not exist as an area of study during the Renaissance, there was an understanding of what described the workings of the mind. In Table 2, this has been summarized as "thought in accordance with signatures". What this means it that the focus of thought was on finding the obscured perfection of God's thoughts in nature and all questions related to thinking were to be framed with this idea as the starting point [57].

The perfection of nature was taken for granted, and that this perfection was known and was revealed in ancient texts - the Bible and ancient Greek and Roman texts. There was nothing to question in this regard. The point of education during this time was to learn the texts and memorize the appropriate response that these texts demanded [58]. Education, in this regard, was characterized by a master calling out the text to be engaged and the students reciting the appropriate answer to the call [59].

Health was then an acceptance of the signs in accessing the signatures of God that came from a correct memorization of ancient knowledge, primarily as given by the ancient physician, Galen [60]. As such, health was right thinking concerning God and interpreted by Galen, and had less to do with a focus on the actual physical health of the individual. Regardless of physical limitations, if a person had the right relationship to God's signature through a Galenic interpreted signs, that person was deemed to have health.

\subsubsection{Classical}

Still yet to be created as a discipline, "psychology" related to an orderly mind during the Classical period - a mind imbedded with a reverence for God but focused on the particulars of God's work, with little actual concern for God's continuing role in those particulars [61]. In this regard, thought was in accordance with the ability to create appropriate categories with the potential for containing infinitesimally divided phenomena.

Education, from this standpoint, was learning how to categorize and hone the ability to recognize and examine objects closely for their minute differences, resulting in the incremental addition of facts as learning progressed. Learning itself, in the regard, was seen to take place in well-defined stages - each one dependent on and adding to the previous stage. Furthermore, to be characterized as educated, the learner was expected to master all the accumulated knowledge and be able to add to it in a similar, graded way - an idea first proposed by Leibniz in 1700 [59] (p. 232).

Once the infinitesimal was understood as having the ability to describe God's work (with the creation of calculus by both Leibniz [62] and Newton [63]) then the idea of the norm could be born. With this birth was the notion of what was to be normally expected with respect to health. As such, people began to gauge their physical and mental health in relation to the norm. Health was then what was normal to expect given a number of 
ways in which people could be categorized [64] (p. 36), for example, by age, weight, diet, living conditions, geographic location, and family situation.

\subsubsection{Modern}

With the Modern period came the naming the discipline of psychology proper [65]. What distinguished this new discipline from previous studies that were thought-related was a concentration on what defined the self with respect to other [66] (p. 572). The self was that which was included within a personally defined boundary and the other was all that was outside that limit. The experience of self, differentiating it from other, was identified through brain processes [67] which could be separated and studied individually.

Education, once psychology became its foundation, now was a search for the unknown and an incorporation of the unknown into the known self [68] (pp. 43-44) by examining nature through individual and intellectually separate disciplines [69] (p. 15). This became a never ending occupation, with the self continually searching for the various ways in which other could be defined, recognized, studied and incorporated into the self through the study of well-defined subjects - a process of reorganizing institutional education that was fully structured by 1920 [59] (p. 235).

With the self as the focus of both psychology and education during the Modern period, health was now directly relevant to an ability to relate to the self-mentally and physically - as a lifestyle [70] (p. 322). This health was dependent on how individual organs functioned and the aim was identifying the self with optimal organic function as an adaption to the environment [71].

\subsection{Table 4}

The ways in which European thought has evolved, according to the analysis of The Order of Things that has been provided for each of psychology, education and health represented the discussion of Table 2. The ordering of these examined areas of thought regards different aspects of science. Science is based on the type of questions posed dependent on what counts as a question. Table 4 presents those questions considered legitimate in each of the three periods of European thought that have been examined.

Question-asking during the Renaissance was limited to asking for guidance in interpreting the way in which a sign related to God's signature. Foucault summarized that the "semantic web of resemblance in the sixteenth century is extremely rich" [11] (p.20). There are multiple notions of how things resemble each other, the purpose of which was to maintain and recognize God's perfection. In this regard, "science" had a preoccupation with a memorization of all the signs that could point to this supremacy.

During the Classical period, the search for minute changes in how nature could be described meant that an aspect of inquiry was either something that was already described or something that required a new name that would accurately categorize it. This was the period when the encyclopedia developed, detailing all the knowledge that had been distinguished and organized [72]. To achieve this organization, something was recognized either as already ordered or not. Thus, the responses to questions that were most revealing in this regard were answered either by "true" or "false" - an idea originating [73] (p. 552) with Spinoza [74].

With the Modern period, the self was now understood as the locus of objectivity [75] (p. 557), with those things that were most evident having the greatest objectivity and those things that were less obvious and known through individual experience being inherently subjective [76]. In this way, questions became narrativized, telling the story of the object while identifying the increasingly subjective nature of the investigation. The questions are thus ordered as such: when, where, who, what, how and why, as represented in Table 5.

\subsection{Implications}

The implications of this analysis of Tables 2 and 4 have much to do with the information provided in Table 3 concerning Foucault's admission that the Modern period 
psychologically can itself be divided into three models of reasoning that were predominant in consecutive eras. What is important to note is that, from today's standpoint, every one of these models of psychological reasoning is still apparent-although the biological and economic currently are overshadowed by the linguistic. With respect to what this means regarding psychology, education and health is to be clarified.

Defining the limits of human thought, psychology is today primarily concerned with the distinction between self and other as well as how it is self can become other in reducing prejudices [77]. However, psychology has maintained the interest in memory that was most notable during the Renaissance when knowing each of the signs of God's signatures was imperative. Furthermore, the focus on measurement, particularly of intelligence, is an aspect of psychology from the Classical period that remains a concentration of current research in psychology.

In comparison with psychology, education is the discipline concerned with the rules regarding the limits of human thought [78]. Although the focus of higher education today is the continued search for what is unknown through asking questions starting from what is most objective to those which are increasingly subjective, in contrast, primary education still is based on reciting the alphabet, counting and learning stories and songs by heart in the same way it was during the Renaissance. Secondary education, differing again, is dependent on answering true or false questions on tests of difficult to differentiate options in which the subtle differences have to be recognized-just as was focus in the Classical period.

Regarding health, although health-related matters are today investigated with respect to the distinct organs involved - as would be expected in the Modern period - similar to both psychology and education, mental health concerns each of the three periods recognized by Foucault. These include diseases involving memory (as in the Renaissance), those concerning attention (originating in the Classical period) and those involving a disassociation with the self (the focus of the Modern period). The diseases of memory include but are not limited to senility, dementia and Alzheimer's. Those of attention involve disorders such as Autistic Spectrum Disorder (ASD) and Attention Deficit Hyperactivity Disorder (ADHD). Diseases creating a disassociation with the self are some of the following: depression, anxiety and body dysphoria.

Two things result from this analysis of these three disciplines. The first is that each of psychology, education and health retains strong imprints of the ways of thinking developed in each of the Renaissance and the Classical period, although the Modern period of thought is upheld as the predominant interest. The second result is that the three periods are incommensurable with each other with respect to the evaluation and ordering of phenomena. Some important points regarding psychology, education and health that can be deduced from this are the following:

1. The success of employing particular psychological methods with respect to research and treatment depends on the focus of human thought demonstrated by the particular person or group of people being investigated.

2. True or false questions are an incompatible form of evaluation when the method of learning is a recitation of signs, as it is predominantly in primary schooling.

3. When education is dependent on making fine distinctions among various particular facts, as is common in secondary education, knowledge of these facts is best determined by answering true or false questions.

4. When the aim of learning is incorporating the unknown into the known, as generally is the interest in higher education, evaluation should concentrate on asking questions of learners that begin with the most objective knowledge and expand to those questions that provide increasingly subjective responses.

5. As the focus of human thought in both the Renaissance and Classical period, though still recognizable in the Modern period, is incommensurable with thought in the Modern period, education at all levels should strive to answer questions ranging from the most objective to increasingly subjective rather than prescribing a period demanding 
recitation similar to Renaissance thinking, or following minute identification - necessary in the Classical period. Consequently, the education that is most compatible with the Modern period in coming to know the unknown can be identified as self-directed learning based on the type and order of questions asked outlined in Table 5.

6. Diseases of memory fit well with the view of human thought that was the focus of the Renaissance; thus, health related to memory is best understood through a reinterpretation of signs rather than evaluation of organs, as is expected in the Modern period of thought.

7. ASD and ADHD are evident as health concerns in educational settings where learning to discriminate and attend to finely divided details is important; to this extent, they arise as health concerns when people are required to make fine discriminations as they would in the Classical period. Self-directed learning avoids the health issues evident in educational settings that focus on evaluating learners in relation to answering true and false questions.

8. The more that the Modern period concentrates its specific concern on the need for self to confront other, the more that depression and anxiety will continue, and increasingly represent, the most prominent health issues for society.

\subsection{Limitations}

In a paper where the claims made are based on narrative research-in this case, the interpretation of one text within the intellectual milieu of other researchers who have also attempted evaluation of it from various perspectives - the most relevant limitations regard the basis of the judgments that have been made as a narrative researcher.

The first is if the text been read as Foucault would have thought appropriate. Foucault was very precise, though difficult to comprehend. Concerned fundamentally with the history of how things have been ordered, he supposedly "hated" that he was called a Structuralist [79] (p. vii) by other theorists who defined him in this way, calling them "half-witted" with "tiny minds' [11] (XV). Given his irritation at being misunderstood, it cannot be assumed that Foucault would have agreed with the results of this analysis. Still, the argument that has been provided in this paper has not made evaluations of Foucault to place him in any particular school of thought and has tried to keep to what Foucault stated as important in his book: "I've tried to see how, in scientific creation, the human subject will be defined as an individual who talks, who works, who lives" [19] (p. 112).

The second limitation is that even if Foucault (who died in 1984 of AIDS [80]) might have approved of this analysis, it could be that there are important aspects to it that he would feel must be mentioned that have been left out. For example, once Foucault has completed his interpretation of the Modern period and the importance of his tri-analysis of it, he then considers where the idea of representation fits [11] (p. 394). His response is "But representation is not simply an object for the human sciences; it is, as we have just seen, the very field upon which the human sciences occur, and to their fullest extent; it is the general pedestal of that form of knowledge, the basis that makes it possible" [11] (p. 396). This point to address was clearly important to Foucault, however, his reply doesn't negate his previous assessment nor alter it for the purpose of this understanding of Foucault in regards to psychology, education and health. Rather, it merely reports representation as an a priori for this analysis.

A third limitation is that The Order of Things is a translation of the original French Les mots et les choses. As such, how the book was translated might differ from the original to the extent that some of the conclusions that have been drawn could be questionable. One way that they might, for example, is that both savoir and connaître are translated as "knowledge" in English. In this regard, there might be a subtleness to Foucault's meaning of knowledge that is missed in The Order of Things. On the other hand, Foucault himself spoke English and the publication of The Order of Things was in 1970-giving Foucault fourteen years before his untimely death at 57 [50] to make changes to the English translation, had he thought they were necessary. The version of The Order of Things used in 
conducting this research was published in 1986. Any changes Foucault might have made to the translation would have been present in it-there were none that were stated.

A fourth limitation is that this type of assessment to ground the disciplines of psychology, education and health in European thought could be wrong-headed. Although The Order of Things may be an influential book and Foucault had things to say about these topics, what he had to say about them might be judged questionable. Habermas, for one, was not convinced by what he considered Foucault's individualistic argument, considering Foucault a Post-Modernist in his assessment of Modernism. In this regard, he was openly hostile to Foucault [81] (page. 3). "For Habermas, one must be careful to distinguish between reason itself and a subject-centred reason. If one does this successfully, then the project of modernity can be saved and a long list of Western thinkers can be despatched (sic) to the reserve shelves of social philosophy... namely... Foucault" [79] (p. 4). Yet, in intellectual competition with Foucault, Habermas perhaps let his personal feelings dictate his assessment of Foucault's version of modernity. Merely because it might be an individualistic rather than sociological view of the Modern period does not mean it is necessary wrong, as Habermas has judged: "Foucault and Habermas met in 1983 and 1984 but this meeting continued a debate in which they had been engaged for several years. It was unlikely that this exchange ever would have led to a dialogue because the protagonists defined 'modernity' in incompatible ways" [82] (p. 221). It is here argued, contrary to Habermas, that value and important insights can be gained from Foucault's understanding of the Modern period in relation to both his views on the Renaissance and Classical period. This is a position argued by other theorists as well [83].

In reading through the position established with this narrative research, it becomes evident that a primary result is that the knowledge provided in each of the three periods elucidated by Foucault cannot be cross-evaluated. This is because he deems them incommensurable. This position is accepted as evident in the work that has been done in this report. However, if so, a fifth limitation would be whether the creation of tables-something corresponding to the Classical period - is relevant to today's researchers in the Modern period. Yet, Foucault also argued that the Modern period, though focused on questions that migrate from the most objective to those that require deeper subjective investigation, still makes use of each of the forms of reasoning relevant since the $16^{\text {th }}$ century. It is because the creation of tables permits the ordering of things in relation to boundariesand boundaries are the focus of this exegesis - that the creation of tables to explain the value of Foucault's work in The Order of Things as might be done in the Classical period, is still reasonable as well as useful during the Modern period.

Even if it is accepted that the creation of these tables is legitimate in the Modern period, a sixth limitation might be whether conducting narrative research as a form of history is the preferred method for making the distinctions among psychology, education and health required to construct the table. That Foucault would consider historical analysis not only an appropriate method but the preferred method for analyzing these divisions is something he specifically stated regarding history.

To each of the sciences of man it offers a background, which establishes it and provides it with a fixed ground and, as it were, a homeland; it determines the cultural area-the chronological and geographic boundaries - in which that branch of knowledge can be recognized as having validity; but it also surrounds the sciences of man with a frontier that limits them and destroys, from the outset, their claim to validity within the element of universality. [11] (p. 405)

Lastly, if all other limitations are found to not hold, the deductions that have been made concerning psychology, education and health may be thought to have overstepped the framework that has been produced in evaluating Foucault's The Order of Things. This represents the seventh possible limitation. If the deductions were ones that were arrived at for the first time as a result of a close reading of this work, then this would be a valid 
concern. However, it is not that the book presented these ideas for the first time to the author. Rather, it was in conducting narrative research on The Order of Things that the author was able to bring together various work done over the course of a research career (for example, [84,85,86,87,88]). The framework of Foucault developed in The Order of Things merely provided a method for making the foundation of this research entirely public and potentially accessible to other researchers.

\section{Conclusions}

Foucault's "Foreward to the English Edition" offers advice to his "ideal reader" of The Order of Things beginning with this statement: "This foreward should perhaps be headed 'Directions for Use'" [11] (p. ix). He lists five important points to remember when reading this work: 1 . Recognize that the study he had undertaken was "a relatively neglected field" [11] (p. ix); 2. Read the book "as a comparative, and not a symptomatological study" [11] (p. x) of the three periods of ordering; 3. Consider that the book is not a usual history of science, that the aim is to try to bring to light "what has eluded that consciousness" [11] (p. xi); 3. Know that The Order of Things was intended as a beginning to an investigation that remained incomplete because of the "problem of change" [11] (p. xii), the "problem of causality" [11] (p. xiii), and the "problem of the subject" [11] (p. xiv). In this way, the only type of further investigation Foucault is against regarding The Order of Thing in augmenting his work is "that which gives absolute priority to the observing subject" [11] (p. xv). Finally, 5. do not consider The Order of Things the work of a Structuralist, "it is only too easy to avoid the trouble of analyzing such work by giving it an admittedly impressive-sounding, but inaccurate, label [11] (p. xv).

The intent of this analysis of Foucault's The Order of Things with respect to what is useful about it in relation to understanding the connections in European thought among investigations in psychology, education and health was to heed Foucault's advice in how to understand this work while providing a supportive framework for other researchers conducting investigations in each of these areas in knowing what methods are appropriate and can provide meaningful results in this regard. It is hoped that the work that has been done here equates this researcher to both and ideal reader of The Order of Things and one of the scholars who has been able to appropriately and effectively extend the progress of Foucault's work as he envisioned for understanding the relationship and limits of psychology, education and health in European thought.

Funding: This research received no external funding.

Acknowledgment: Thank you to Mik Tampold for gifting the author a copy of The Order of Things December 2019, providing the stimulus for this article.

Conflicts of Interest: The author declares no conflict of interest.

\section{References}

1. Frankham, C.; Richardson, T. and Maguire, N. Psychological factors associated with financial hardship and mental health: A systematic review. Clin. Psychol. Rev. 2020, 77, 101832-101832. https://doi.org/10.1016/j.cpr.2020.101832

2. Zürcher. C.; Tough, H.; Fekete, C. for the SwiSCI Study Group. Mental health in individuals with spinal cord injury: The role of socioeconomic conditions and social relationships. PLoS ONE 2019, 14, e0206069. https://doi.org/10.1371/journal.pone.0206069

3. O'Higgins, A.; Ott, E.M. and Shea, M.W. What is the Impact of Placement Type on Educational and Health Outcomes of Unaccompanied Refugee Minors? A Systematic Review of the Evidence. Clin. Child Fam. Psychol. Rev. 2018, 21, 354-365. https://doi.org/10.1007/s10567-018-0256-7

4. Ebert, D.D.; Van Daele, T.; Nordgreen, T.; Karekla, M.; Compare, A.; Zarbo, C.; Brugnera, A.; Øverland, S.; Trebbi, G.; Jensen, K.L.; Kaehlke, F. and Baumeister, H. Internet- and Mobile-Based Psychological Interventions: Applications, Efficacy, and Potential for Improving Mental Health: A Report of the EFPA E-Health Taskforce. Euro. Psychol. 2018, 23, 167-187. https://doi.org/10.1027/1016-9040/a000318 
5. Wittink, H. and Oosterhaven, J. Patient education and health literacy. Musculoskel. Sci. Prac. 2018, 38, 120-127. https://doi.org/10.1016/j.msksp.2018.06.004

6. Horlings, A. and Hein, I. Psychiatric screening and interventions for minor refugees in Europe: an overview of approaches and tools. Euro. J. Pedia. 2018, 177, 163-169. https://doi.org/10.1007/s00431-017-3027-4

7. Sukys, S.; Trinkuniene, L.; Tilindiene, I. Subjective Health Literacy among School-Aged Children: First Evidence from Lithuania. Int. J. Environ. Res. Public Health 2019, 16, 3397. https://doi.org/10.3390/ijerph16183397

8. Luchetti, M.; Terracciano, A.; Stephan, Y.; Aschwanden, D. and Sutin, A. R. Personality Traits and Memory: A Multilevel Analysis Across 27 Countries From the Survey of Health, Ageing and Retirement in Europe. Psychol. Sci. 2021, 32, 1047-1057. https://doi.org/10.1177/0956797621993101

9. Cao, Q.-T.; Vuong, Q.-H.; Pham, H.-H.; Luong, D.-H.; Ho, M.-T.; Hoang, A.-D.; Do, M.-T. A Bibliometric Review of Research on International Students' Mental Health: Science Mapping of the Literature from 1957 to 2020. Eur. J. Investig. Health Psychol. Educ. 2021, 11, 781-794. https://doi.org/10.3390/ejihpe11030056

10. Foucault, M. Les mots et les choses : une archéologie des sciences humaines. Gallimard: Paris, France, 1966.

11. Foucault, M. The Order of Things: The Archeology of Human Sciences, $1^{\text {st }}$ published by Tavistock Publications, United Kingdom, 1970; Routledge Classics: New York, New York, U.S.A., 1989.

12. Savigneau, J. Ecrivains et choix sentimentaux. Le Monde 15 octobre 1999. Available online: https://www.lemonde.fr/archives/article/1999/10/15/ecrivains-et-choix-sentimentaux $35701701819218 . h t m l$ (accessed on 6 January 2022).

13. Durnová, A. Understanding Emotions in Policy Studies through Foucault and Deleuze. Polit. Govern. 2018, 6, 95102. https://doi.org/10.17645/pag.v6i4.1528

14. Hughes, A. Positioning Indigenous knowledge systems within the Australian mathematics curriculum: investigating transformative paradigms with Foucault, Discourse: Stud. Cultur. Poli. Educ. 2021,42, 487498, DOI: $\underline{10.1080 / 01596306.2020 .1715345}$

15. Fraser, S.; Moore, D.; Waling, A. and Farrugia, A. Making epistemic citizens: Young people and the search for reliable and credible sexual health information. Soc. Sci. Med. 2021, 276, 113817-113817. https://doi.org/10.1016/j.socscimed.2021.113817

16. Moore, J.H. Foucault, "The Order of Things, An Archaeology of the Human Sciences" (Book Review) [Review of Foucault, "The Order of Things, An Archaeology of the Human Sciences" (Book Review)]. Sci. Soc. 1971, 35, 490-494. Available online: https://www.jstor.org/stable/40401605 (accessed on 8 January 2022).

17. Jahoda. M. Review: Foucault, Michel, The Order of Things: An Archaeology of the Human Sciences. London: Tavistock Publications Ltd., $1970 . \quad$ p. $387 £ 3.75$ Soc. Stud. Sci. 1972, 2, 99-103. https://doi.org/10.1177/030631277200200104

18. Kennedy, D. Michel Foucault: The Archaeology and Sociology of Knowledge. Theor. Soc. 1979, 8, 269-290. https://doi.org/10.1007/BF00171367

19. Fornet-Betancourt, R.; Becker, H.; Gomez-Müller, A. and Gauthier, J. D. The Ethic of Care for the Self as a Practice of Freedom: An Interview with Michel Foucault on January 20, 1984. Phil. Soc. Crit. 1987, 12, 112-131. https://doi.org/10.1177/019145378701200202

20. Descombes, V. The Order Of Things: An Archaeology Of What? Hist. Theor. 2016, 55, 66-81. https://doi.org/10.1111/hith.10829

21. Wertz, F.J. Five ways of doing qualitative analysis : phenomenological psychology, grounded theory, discourse analysis, narrative research, and intuitive inquiry; Guilford Press: New York, New York, 2011.

22. Bruner, J.S. Actual Minds, Possible Worlds; Harvard University Press: Cambridge, Mass., U.S.A., 1986.

23. Emden, C. Theoretical perspectives on narrative inquiry. Collegian 1998, 5, 30-35. https://doi.org/10.1016/S13227696(08)60281-4

24. Overcash, J.A.. Narrative research: a review of methodology and relevance to clinical practice. Crit. Rev. Onc./hema. 2003, 48, 179-184. https://doi.org/10.1016/j.critrevonc.2003.04.006

25. Moen T. Reflections on the Narrative Research Approach. Inter. J. Qual. Meth. December 2006, 56-69. doi:10.1177/160940690600500405

26. Rajan, T. The Phenomenological Allegory: From "Death and the Labyrinth" to "The Order of Things." Poetics Today 1998, 19, 439-466. https://doi.org/10.2307/1773428

27. Popper, K. The Logic of Scientific Discovery; Hutchinson Press: London, Great Britain, 1959.

28. Kuhn, T.S. The Structure of Scientific Revolutions; University of Chicago Press: Chicago, Ill., U.S.A., 1970.

29. Lakatos, I. The Methodology of Scientific Research Programmes; Lakatos, I., Musgrave, A., Eds. Criticism and the Growth of Knowledge; Cambridge University Press: London, Great Britain, 1970. 
30. Feyerabend, P. Against Method, 1st published 1975; Verson Press: London, Great Britain, 1975.

31. Hacking. I. Michel Foucault's Immature Science. Nô̂s 1979, 13, 39-51. https://doi.org/10.2307/2214794

32. Modell. A.H. Not Even Wrong. Psychoan. Inquir 2011, 31, 126-133. https://doi.org/10.1080/07351690.2010.515855

33. Gilbert, G.N. The Transformation of Research Findings into Scientific Knowledge. Soc. Stud. Sci. 1976 6, 281-306. http://www.jstor.org/stable/284685

34. Foucault, M. The Order of Things; Pantheon Books: New York, New York, U.S.A., 1970. Available online: https://search.alexanderstreet.com/view/work/bibliographic_entity\%7Cbibliographic_details\%7C3995904 (accessed on 11 January 2022).

35. Ludwig, W. Astrology in Antiquity, in the Renaissance, and Today. Arts: J. Sydney Uni. Arts Assoc. 2005, $27,432$. Available online: https://openjournals.library.usyd.edu.au/index.php/ART/issue/view/432 (accessed on 17 January 2022).

36. Butterfield, H. The Origins of Modern Science, 1300-1800; Rev. Free Press: New York, New York, U.S.A., 1965.

37. Descartes, R. Discourse on Method and the Meditations; Sutcliffe, F.E., Trans.; Penguin Books: New York, New York, U.S.A., 1968

38. Kinsman, R.S.. The Darker Vision of the Renaissance: Beyond the Fields of Reason, University of California Press: Berkeley, Calf., U.S.A., 2020. https://doi.org/10.1525/9780520310032

39. Brenner, N. Foucault's New Functionalism. Theor. Soc. 1994, 23, 679-709. https://doi.org/10.1007/BF00992907

40. Sciortino. L. The emergence of objectivity: Fleck, Foucault, Kuhn and Hacking. Stud. Hist. Philo. Sci. 2021, 88, 128137. https://doi.org/10.1016/j.shpsa.2021.06.005

41. Broberg, G. 2. The Broken Circle. The Quantifying Spirit in the Eighteenth Century; Frängsmyr T., Heilbron, J.L., Rider, R.E. Eds.; University of California Press: Berkeley, Calf., U.S.A., 2020; pp. 4572. https://doi.org/10.1525/9780520321595-004

42. St.Pierre, E.A. The Lure of the New and the Hold of the Dogmatic. Qual. Inqu. 2021, 27, 480-490. https://doi.org/10.1177/1077800420939133

43. Mader, M.B. SIX/Foucault, Cuvier, and the Science of Life. Biopower : Foucault and beyond; Cisney, V.W., Morar, N. Eds. The University of Chicago Press: Chicago, Ill., U.S.A., 2016. https://doi.org/10.7208/9780226226767

44. McGushin E. Foucault and the problem of the subject. Philo. Soc. Crit. 2005, 31, 623-648. doi:10.1177/0191453705059664

45. Polanyi, M. The Logic of Tacit Inference. Philosophy, 1966, 41, 1-18. doi:10.1017/S0031819100066110

46. Koestler, A. The Sleepwalkers; Penguin UK: London, Great Britain, 1986.

47. Copernicus, N. De revolutionibus orbium coelestium; Johannes Petreius: Nuremberg, Holy Roman Empire, 1543.

48. Deacon, R. Truth, Power and Pedagogy: Michel Foucault on the rise of the disciplines. Educa. Philos. Theor. 2002, 34, 435-458. https://doi.org/10.1111/j.1469-5812.2002.tb00518.x

49. Flammer, A. Towards a theory of question asking. Psych. Res. 1981, 43, 407-420. https://doi.org/10.1007/BF00309225

50. Comte, A. Discours sur l'ensemble du positivisme; La Librairie Scientifique-Industrielle de L. Mathias: Paris, France, 1848.

51. Comte, A. A General View of Positivism; Bridges, J.H. Trans. Trübner and Co.: London, Great Britain, 1865.

52. Marx, K. Das Kapital: Kritick der politischen Oekonomie. Buch 1: Der Produktionsprocess des Kapitals; Verlag von Otto Meissner: Hamburg, Germany, 1867.

53. Marx, K. Capital: A Critical Analysis of Capitalist Production, Vol. 1; Engels, F. Ed., Moore, S., Aveling, E., Trans.; Swan Sonnenschein, Lowrey, \& Co.: London, Great Britain, 1887.

54. Freud, S. Die Traumdeutung; Franz Deuticke: Leipzig und Wien, Austria, 1900.

55. Freud, S. The Interpretation of Dreams; Brill, A.A. Trans.; The MacMillan Company: New York, New York, U.S.A., 1913.

56. Comte, A. Cours de philosophie positive: La partie dogmatique de la philosophie sociale; Bachelier: Paris, France, 1839.

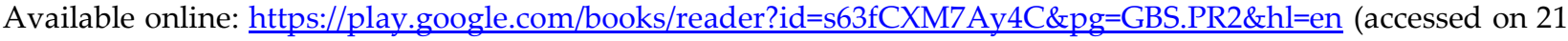
January, 2022).

57. Blair, A. Mosaic Physics and the Search for a Pious Natural Philosophy in the Late Renaissance. Isis 2000, 91, 3258. https://doi.org/10.1086/384625

58. Charlton, K. Education in Renaissance England; Routledge: New York, New York, U.S.A., 2007; p. 15. DOI: 10.4324/9780203717479

59. Collins, R. Comparative and Historical Patterns of Education. In Handbook of the Sociology of Education; Hallinan, M.T. Ed.; Springer: New York, New York, U.S.A. pp. 213-239. https://doi.org/10.1007/0-387-36424-2_10 
60. García Ballester, L. Galen and Galenism : theory and medical practice from antiquity to the European Renaissance; Ashgate: Burlington, Vermont, U.S.A., 2002.

61. Kubrin, D. Newton and the Cyclical Cosmos: Providence and the Mechanical Philosophy. J. Hist. Ideas 1967, 28, 325-346. https://doi.org/10.2307/2708622

62. Leibniz, G. Nova Methodus Pro Maximis. Acta Eruditorum 1684, 467-488. Available online: https://www.scribd.com/document/117368276/Leibniz-Acta-Eruditorum (accessed on 16 January 2022).

63. Newton, I.S. Philosophiae Naturalis Principia Mathematica. S. Pepys, Reg. Soc. Praeses: London, England, 1687. Availbable online: https://www.gutenberg.org/files/28233/28233-h/28233-h.htm (accessed on 16 January 2022 ).

64. Lock, M. and Nguyen, V-K. An Anthropology of Biomedicine, $2^{\text {nd }}$ edition; John Wiley and Sons: Hoboken, New Jersey, U.S.A., 2018

65. Bunge, M. What kind of discipline is psychology: Autonomous or dependent, humanistic or scientific, biological or sociological? New Ideas Psychol. 1990, 8, 121-137. https://doi.org/10.1016/0732-118X(90)90002-J

66. Abraham, C.; Sheeran, P. and Johnston, M. From health beliefs to self-regulation: Theoretical advances in the psychology of action control. Psychol. Health 1998, 13(4), 569-591. https://doi.org/10.1080/08870449808407420

67. Vogeley, K. and Gallagher, S. Self in the Brain. Oxford Handbooks Online, 2011. https://doi.org/10.1093/OXFORDHB/9780199548019.003.0005

68. Egan, K. The educated mind: How cognitive tools shape our understanding; University of Chicago Press: Chicago, Ill., U.S.A., 1997. https://doi.org/10.7208/9780226190402

69. Popkewitz, T.S. Curriculum history, schooling and the history of the present. Hist. Educ. 2011, 40, 1-19. https://doi.org/10.1080/0046760X.2010.507222

70. Cockerham, W.C.; Rütten, A. and Abel, T. Conceptualizing Contemporary Health Lifestyles: Moving Beyond Weber. Sociol. Quart. 1997, 38, 321-342. https://doi.org/10.1111/j.1533-8525.1997.tb00480.x

71. Kovacs, J. The concept of health and disease. Med. Health Care Phil. 1998, 1, 31-39. https://doi.org/10.1023/A:1009981721055

72. Rosenberg, D. An Eighteenth-Century Time Machine: The "Encyclopedia" of Denis Diderot. Histor. Reflec., 1999, 25(2), 227-250. Available online: https://www.jstor.org/stable/41299144 (accessed on 27 January 2022).

73. Schacter, D.; Gilbert, D.; Wegner, D. and Hood, B.M. Psychology: European Edition; Palgrave Macmillan: New York, New York, U.S.A., 2012.

74. Curley, E. Spinoza on truth. Australasian J.Philo. 1994, 72, 1-16. https://doi.org/10.1080/00048409412345841

75. Kasulis, T.P. Engaging Japanese Philosophy: A Short History; University of Hawaii Press: Honolulu, Hawaii, U.S.A., 2018.

76. Leopold, D. Alienation. The Stanford Encyclopedia of Philosophy (Fall 2018 Edition); Zalta, E.N., Ed. 2018. Available online: https://plato.stanford.edu/archives/fall2018/entries/alienation/ (accessed on 25 January 2022).

77. Greenwald, A.G. and Banaji, M. R. Implicit Social Cognition: Attitudes, Self-Esteem, and Stereotypes. Psychol. Rev. 1995, 102, 4-27. https://doi.org/10.1037/0033-295X.102.1.4

78. Jerome Bruner. Culture, Mind, and Education. The Culture of Education; Harvard University Press: Cambridge, Massachusetts, U.S.A., 1997; pp.1-43.

79. Dreyfus, H.L. and Rabinow, P. Michel Foucault: Beyond Structuralism and Hermeneutics; Routledge: New York, New York, U.S.A., 1982. https://doi.org/10.4324/9781315835259

80. Miller, J. The Passion of Michel Foucault; Simon \& Schuster: New York, New York, U.S.A., 1993.

81. Burrell, G. Modernism, Postmodernism and Organizational Analysis 4: The Contribution of Jürgen Habermas. Organiz. Stud. 1994, 15, 1-19. https://doi.org/10.1177/017084069401500101

82. Burrell, G. Modernism, Postmodernism and Organizational Analysis 2: The Contribution of Michel Foucault. Organization Studies, 1988, 9, 221-235. https://doi.org/10.1177/017084068800900205

83. Ashenden, S. and Owen,D. Introduction: Foucault, Habermas and the Politics of Critique; Ashenden, S. and Owen, D. Eds. Foucault contra Habermas: Recasting the Dialogue between Genealogy and Critical Theory; Sage Publications. London, U.K., 1999.

84. Nash, C. Challenges to Learners in Interpreting Self as Other, Post COVID-19. Challenges $2021,12,31$. https://doi.org/10.3390/challe12020031

85. Nash, C. Medical Professionals Require Curricula Support to Overcome Their Reluctance to Embrace Self-Directed Learning in Response to COVID-19. Med. Sci. Forum 2021, 4, 20. https://doi.org/10.3390/ECERPH-3-08986

86. Nash, C. Disorder in ADHD and ASD Post-COVID-19. COVID 2021, 1, $153-165$. https://doi.org/10.3390/covid1010014. 
87. Nash, C. Reconsidering Privilege: How to Structure Writing Prompts to Develop Narrative. Survive E Thrive: J Med. Human. Narrat. Med. 2020, 5, 3. Available at: https://repository.stcloudstate.edu/survive_thrive/vol5/iss2/3.

88. Nash C. Challenges Identifying and Stimulating Self-Directed Learning in Publicly Funded Programs, The Digital Era of Education: Novel Teaching Strategies and Learning Approaches Designed for Modern Students; Nova Science Publishers, Inc: Hauppauge, New York, U.S.A., 2020; pp. 259-300. 